\title{
The Effectiveness of Problem Based Learning (PBL) Method through Marquee Model to Cultivate Literacy
}

\author{
Indah Mei Diastuti ${ }^{*}$, Agus Sulton ${ }^{2}$ \\ 1,2 Universitas Hasyim Asy'ari Tebuireng Jombang, Indonesia
}

maidiastuti@gmail.com*

\begin{tabular}{|c|c|}
\hline & Abstract \\
\hline & $\begin{array}{l}\text { The aim of this study was to determine the effectiveness of the Problem Based } \\
\text { Learning (PBL) method to cultivate students' literacy. By using the marquee }\end{array}$ \\
\hline ARTICLE INFO & model, the students can focus on writing which would be the topic of problems \\
\hline $\begin{array}{l}\text { Article history: } \\
\text { Received }\end{array}$ & $\begin{array}{l}\text { that would be discussed through the PBL method. The method used a quasi } \\
\text { experimental design. The result of this research showed that PBL method }\end{array}$ \\
\hline $\begin{array}{l}\text { November } 07 \text {, } \\
2020\end{array}$ & $\begin{array}{l}\text { through Marquee media was effective to improve the literacy culture of students } \\
\text { at Universitas Hasvim Asy'ari (UNHASY) Tebuireng Jombang. The literacy }\end{array}$ \\
\hline Revised & culture before using PBL method through Marquee was $75 \%$ of children rarely \\
\hline $\begin{array}{l}\text { November } 29 \text {, } \\
2020\end{array}$ & $\begin{array}{l}\text { do literacy activities. After using PBL method through Marquee was } 90 \% \\
\text { children often do literacy activities. Hence, it can be concluded that the problem }\end{array}$ \\
\hline Accepted & basic learning (PBL) method through marquee can improve the students' \\
\hline $\begin{array}{l}\text { December } 28 \text {, } \\
2020\end{array}$ & $\begin{array}{l}\text { literacy culture of Indonesian language and literature education, mathematics } \\
\text { education. Because there was an increase from } 75 \% \text { to } 90 \% \text { of students who like } \\
\text { to read, this indicates that PBL through marquee was effective in improving } \\
\text { literacy culture. }\end{array}$ \\
\hline
\end{tabular}

Published by

Keyword: Problem Based Learning, Marquee Model, Cultivate Literacy

Website

Lembaga Penelitian dan Pengabdian Kepada Masyarakat

Institut Agama Islam Negeri Metro

http://e-journal.metrouniv.ac.id/index.php/tapis/index

This is an open access article under the CC BY SAlicense

https://creativecommons.org/licenses/by-sa/4.0/

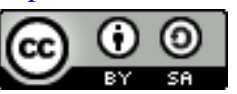

\section{INTRODUCTION}

Education in Indonesia as a measuring tool to determine how advanced a nation can be seen from the education in a country. Hence, Literacy culture would have a very good competitiveness. In the fact, literacy culture is considered not so important in Indonesia. It is very unfortunate that currently Indonesia is experiencing a literacy crisis, even though literacy plays an important role in a society with character (Lopus, Amidjono, \& Grimes, 2019; Suwana, 2017). The very rapid development of technology help in providing information to the public quickly but it is not necessarily accurate. Those are because people only listen and watch without getting used to read first, so the information obtained is not completely correct. Currently cultivating literacy in society is still not optimal because people are still lulled by instant information. Whereas by doing reading activity, the other language skills can emerge by themselves. By doing reading activity, we can produce writing, speak intellectually, be good listeners of information, etc. In this digital era, information literacy is the ability to find out what information is currently developing, solve problems, develop ideas, ask important questions, so that you can use the information appropriately, relevant and effectively to deal with issues or problems that are developing in the community. According to Buckingham (2013) literacy consists of seven principles of education, namely interpretation, collaboration, convention, cultural knowledge, solution to problem, reflection and self-reflection, and the use of language.Students are one of the literacy culture developers. The teaching and learning process carried out by lecturers and students often unintentionally produces literacy, but it is

Doi http://dx.doi.org/10.32332/tapis.v4i2.2573

ISSN Print 2579-3233; Online 2580-068X

| Volume 4 Number 2, December 2020, page 220-225 
often not optimal. One of the factors is the teaching and learning process which has not led to a culture of literacy.

The relevant research from Sumitro (2017) that disscussed the application of problembased learning model to increase motivation and social studies learning outcomes. The results of this study was the increase motivation and social studies learning outcomes. It is proven from the data results of research that there was an increase in student motivation in the four aspects in detail. Firstly, the attention aspect in cycle 1 is increased $11.28 \%$, from $73.04 \%$ to $84.32 \%$ (cycle II). Second, the relevance aspect is also increased $9.64 \%$ from $76.55 \%$ (cycle I) to $86.19 \%$ (cycle II). Third is the aspect of confidence, it increased $10.62 \%$ from $71.56 \%$ in cycle I to $82.18 \%$ in cycle II,. And last is the satisfaction aspect increased $14.88 \%$ from $71.79 \%$ in cycle I to $86.67 \%$ in cycle II. Learning outcomes increased $14.29 \%$ from $71.42 \%$ in cycle I to $85.71 \%$ in cycle II. These results indicate that the Problem Based Learning model can increase student motivation and learning outcomes. Meanwhile, Oktarina (2015) with the title the effectiveness of using Marquee Media in Improving Reading Skills for Class VI Students of SDN 81/ II Muara Bungo. It can be concluded that the Marquee media is effective in improving the speed reading skills of grade VI students of SDN 81/ II Muara Bungo. The last relevant article is the research from Syafei (2015) entitled Literacy Traditions in Islamic Higher Education: Views and Motivations of the Authors of the journal Al-Ahwal UIN Sunan Kalijaga Yogyakarta. This study reveals that the motivation to write articles in journals is not based on fulfilling physiological needs and safety needs as in Maslow's hierarchy of needs, nor is it driven by needs in Alderfer's theory. The tradition of writing in Al-Ahwal's journal is more motivated by social needs and self-actualization in Maslow's theory, or based on factors to meet the needs of social relations and self-development as found in Alderfer's theory. The difference between this study and previous research was in using media. This researchers used marquee media to improve reading skills, and cultivate students in reading literacy. The purpose of this study was to determine the effectiveness of the PBL method so that students cultivate reading literacy, and also by using the marquee model so that students focus on writing which would be the topic of problems. The urgency of this research is to civilize students with literacy because so far students tend to listen and watch more through YouTube or other media so as it reduces the literacy culture.

\section{METHOD}

According to Nana S. Sukmadinata (2010), quantitative research is based on the philosophy of positivism which emphasizes objective phenomena that are studied quantitatively or carried out using numbers, statistical processing, structure, and controlled experiments. While the type of research used in this research is quasi experimental design research. Sugiyono (2007) defines that experimental research is research that is used to find the effect of certain treatments on others under controlled conditions. A similar opinion was also expressed by Suharsimi Arikunto (2000) who defines experimental research as research that is intended to determine whether or not there are consequences of treatment on the subject under investigation. The way to find out is to compare one or more experimental groups who were given treatment with a comparison group who were not given treatment.. The researcher used a quasi experimental design because the researcher used 2 classes as the subject class, the second semester of Mathematics study program as the control class and the 2nd semester of Indonesian Language and Literature study program class as the experimental class. The subjects of this research were students of the 2nd semester of Mathematics Education study program of 2019 (control group) and 2nd semester of Indonesian Language and Literature Study Program of 2019 (experimental group) in the Faculty of Education, Hasyim Asy'ari Unibersity Tebuireng, Diwek, Jombang, East Java. The experimental group students totaled 13, while the control group students numbered 13. This study took the student subjects which is not much different because they received the same treatment from the researchers themselves as lecturers. In this study, the learning in experimental group was carried out using PBL method through marquee media, and for the learning in control group was carried out using PBL method but did not use 
marquee media. The researcher chose the test method as a comparison between the two classes. Research variables are attributes or properties or values of people, objects or activities with certain variations that are determined by the researcher to be studied and then draw conclusions,

\section{RESULT AND DISCUSSION}

The results obtained in this study were in three discussions. Those are (1) literacy culture before receiving PBL method treatment through marquee media, (2) literacy culture after receiving PBL method treatment through marquee media (3) the comparison of results before treatment and after after receiving PBL method treatment through marquee media.

\section{Literacy culture before receiving PBL method treatment through Marquee Media}

The initial condition of students of the 2nd semester of Mathematics Education study program and 2nd semester of Indonesian Language and Literature Study Program after being carried out by pretesting through several questions through questionnaires related to literacy, it turns out that $75 \%$ rarely do literacy activities on campus or at home or cottage. There are many reasons they explain why they do not like reading. One of which is because they prefer watching and listening instead of reading. For them reading is very boring and makes them sleepy quickly. Based on the results of the test, the researcher conducted further treatment in the Control class (mathematics education students) using the PBL learning method and the Experiment class (Indonesian language and literature education students) using the PBL Learning Method through the marquee media.

In this condition, the second semester of Indonesian language and literature education study program (PBSI) students were experimental classes. After being pretested through several questions by using questionnaires related to literacy, it turned out that $70 \%$ of the total PBSI students were in the "Rarely" category in doing literacy activities on campus or at home or collage. This is proven with the results of the questionnaire that students have filled in. Many of the reasons they do not really like reading because they prefer watching and listening instead of reading. For them, reading is very boring and makes them sleepy quickly. Based on the results of these tests, the researcher conducted further treatment in the Control class of Mathematics education study program (PMTK) by using the PBL learning method and the Experiment class (PBSI) using the PBL Learning Method through the marquee media.

\section{Literacy culture after receiving PBL method treatment through Marquee Media}

In the control class, the learning was treated by using PBL method. By using Aris Shoimin's theory of PBL learning steps (no steps were changed by the researcher) and the results shown in this control class that the students are still unable to focus on the text that is read by the researcher (lecturer) in the form of a sheet containing text where students are required to find problems that exist in the text. It turns out that only $79 \%$ of students actually read the text diligently and comprehensively.

Literation culture after receiving PBL method treatment through Marquee Media in the Experiment class (Indonesian language and literature education students). How the literacy culture of UNHASY students after receiving treatment using the PBL learning method through marquee media is. The learning trials with the PBL method, according to Eggen \& Kauchak (2012: 307) Problem Based Learning is a set of teaching models that use problems as a focus for developing problem-solving skills, materials, and self-regulation. Researchers use the PBL method because students are able to solve a problem that the researcher gives during the lecturing process. In the fact, they cannot focus on solving the problem because they do not focus on the reading that the researcher gives each group of paper and even they do not read it; this is the treatment in the Control class ( mathematics education students). The same treatment is treated in the experimental class (Indonesian language and literature education students). In this class the researchers used the PBL method through the marquee media, namely walking writing with added marquee media. The learning process with the PBL method made students more focused on finding problems that were displayed in the running text because students indirectly carrying out reading activities by finding problems that will be used as problem 
solving skills through discussion. Then the researcher gave a test with the results obtained for the literacy activities of the control class students (Mathematics education students) and the experimental class (Indonesian language and literature education students) experienced a very significant change in these results. It is proven by asking several questions using a questionnaire related to literacy, the results obtained that $90 \%$ of PBSI students "often" do literacy.

After going through the trial phase using the PBL method through the marquee, the results obtained that they experienced a change. This was evidenced by asking several questions using questionnaires related to literacy. The results obtained were that $90 \%$ of Mathematics Education study program students and Indonesian Language and Literature Study Program students often did literacy .

\section{The Comparison of the results before and after treatment with the PBL method through Marquee Media}

The comparison of the results obtained from the results of literacy culture before and after using the PBL method through Marquee was before treatment $75 \%$ of students rarely did literacy activities and after treatment $90 \%$ of students often did literacy activities. So it can be concluded that the problem basic learning (PBL) method through marquee can improve the literacy culture of Mathematics Education study program students and Indonesian Language and Literature Study Program students. It is proven by the increase from $75 \%$ to $90 \%$ who like to read. This indicates that PBL through marquee is effective in improving literacy culture. The result of this research was problem basic learning (PBL) method can be combined with one appropriate media, in order to achieve a goal. This study does not require an analysis of the value produced by students because it is not intended to know students 'abilities but to assess students' literacy culture and literacy culture that cannot be assessed.

Other result reported that the students' environmental literacy can be improved through classroom learning by applying Problem Based Learning model (Febriasari, \& Supriatna, 2017). Using Problem Based Learning run effectively, efficiently, and get maximum result, and efforts to improve environmental literacy should be sustainable. The results also showed that the learning model PBL provided opportunities for students to learn thinking analytically and try to solve their problems. This provides a positive impact students' understanding that will bring positive contribution to their scientific literacy (Ardianto, D., \& Rubini, B. (2016).. This is in line with the results of several studies (Brickman, et al, 2009; Balim 2009; Alfiery 2011, and Nbi- na, 2013) which stated that learning process that gives students the chance to be actively involved in gathering knowledge process in literacy. The results of this study have implications for improving literacy culture in all students from kindergarten to the university level. The method is very applicable. And for other education practitioners, they can also develop and use other methods than PBL but still using the marquee method. Lastly, the researcher hope for other educational researchers to develop better so that they can be even more useful. This study produces a PBL method that is different from the usual because this research uses marquee media where this media is expected to help students to read literacy in accordance with the original purpose of this study that marquee media can cultivate reading literacy in students. The difference between this study and previous research is that it lies in the media used and the desired results. In the previous research, the marquee media was only to help students to read the text quickly, while this study was to cultivate students to read literacy.

The contribution of this research is that there has never been a combination of PBL learning methods combined with marquee media. Most of the PBL method is used to improve a lesson that initially did not go well. However, in this study we tried to use the PBL method where the students were given directions to find problems through a text. The uniqueness of this learning was the text formed in marquee media or walking text with the aim of students being more focused on the text displayed and really serious about reading. This research tries to develop PBL method with marquee media, whether it can be developed for other learning contributions and not only to cultivate student literacy. 


\section{CONCLUSION}

The conclusion of this study is that the Problem Basic Learning method through Marquee media is very effective in improving the literacy culture of students at Hasyim Asy'ari University. It is proven that there is an increase in the beginning before the treatment with the PBL method through Marquee. The percentage of students in the control class and the experimental class $75 \%$ rarely cultivates literacy. Then the percentage increased to $90 \%$ of students often practicing literacy culture after being treated by the PBL method through Marquee media. So it can be concluded that the PBL method through Marquee media is effective in improving the literacy culture of UNHASY students.

\section{ACKNOWLEDGEMENT}

The research's sincere appreciation goes to the Dean of the Faculty of Education, Hasyim Asy'ari tebuireng Jombang University, who has given permission to do the research. Then, thanks for the guidance that has motivated to immediately complete this research. This research is a research funded by the Ministry of Education and Culture entitled: The Effectiveness of Problem-Based Learning (PBL) Method through Marquee Media to Cultivate Literacy. Thanks are addressed to the Ministry of Technology Research and Higher Education of the Republic of Indonesia for research funds provided under a grant scheme: for beginner lecturer research in 2020. Thank you also to all students of the Indonesian Language Study Program and the Mathematics Education study program, for their contribution to this research.

\section{AUTHOR CONTRIBUTION STATEMENT}

Indah Mei Diastuti, is the lead author of this article. Agus Sulton is the second author who provides support and motivation. Indah as the main researcher is a lecturer in Indonesian Language and Literature Education. Indah conducts lectures while developing research on the Effectiveness of the Problem-Based Learning (PBL) Method through Marquee Media to Cultivate Literacy. While Agus helps researchers in evaluating the implementation of lectures, while ensuring that the lecture can be said to be able to cultivate literacy by using the ProblemBased Learning Method (PBL) through Marquee Media.

\section{REFERENCES}

Arikunto, Prof. Dr. Suharsimi. 2000. Manajemen Penelitian. Jakarta: PT. Rineka Cipta.

Ardianto, D., \& Rubini, B. (2016). Comparison of students' scientific literacy in integrated science learning through model of guided discovery and problem based learning. Jurnal Pendidikan IPA Indonesia, 5(1), 31-37. Google Scholar

Alfieri, L., Brooks, P.J. \& Aldrich, J.N. (2011). Does Discovery-Based Instruction Enhance Learning?. Journal of educational Psycology, (103) 1, 1-18. https://psycnet.apa.org/doi/10.1037/a0021017

Balim, A.G. (2009). The Effect of Disco-very Learning On Student's Success and Inquiry Learning Skills.Eurasian Journal Of Educational Research. (35): 1-20. Google Scholar

Brickman, P., Gormally, C., Armstrong, N \& Hallar, B. (2009). Effects of Inquiry-Based Learning on Students'science Literacy Skills dnd Confidence. International Journal for the Scholarship of Teaching and Learning. (3)2. Google Scholar

Buckingham, D. (2013). Media education: Literacy, learning and contemporary culture. John Wiley \& Sons. Google Scholar

Febriasari, L. K., \& Supriatna, N. (2017). Enhance environmental literacy through problem based learning. JPhCS, 895(1). https://doi:10.1088/1742-6596/895/1/012163

Huang, K. S., \& Wang, T. P. (2012). Applying problem-based learning (PBL) in University English translation classes. The Journal of International Management Studies, 7(1), 121127. Google Scholar

Kementrian pendidikan dan Kebudayaan.(2016). Manual Pendukung Pelaksanaan Gerakan Literasi Sekolah. Jakarta: Kemdikbud. dst. 
Lopus, J. S., Amidjono, D. S., \& Grimes, P. W. (2019). Improving financial literacy of the poor and vulnerable in Indonesia: An empirical analysis. International Review of Economics Education, 32, 100168. https://doi.org/10.1016/j.iree.2019.100168

Maulidya, F., Mudzakir, A., \& Sanjaya, Y. (2014). Case study the environmental literacy of fast learner middle school students in Indonesia. environmental education, 1, 6. Google Scholar

Muniamal.(2015). Innovative English language acquisition through problem-based learning in Malaysian polytechnic.Proceedings of Ninth The IIER International Conference, ,Bangkok Thailand ,79-81

Nbina, J. B. (2013). The Relative Effecti-veness of Guided Discovery and Demonstration Teaching Methods on Achievement of Chemistry Students of Different levels of Scientific Literacy. Journal of Research in Education and Society. (4) 1, 8-13. Google Scholar

Oktarina Y. dkk. 2018. Efektivitas Penggunaan Media Marquee dalam Meningkatkan Keterampilan Membaca Memindai Siswa Kelas VI SDN81/II Muaro BungoTunas . Pendidikan Vol1 No1.

Rohim, A. (2014). Improving students' speaking skill through problem based learning (PBL) strategy. JP3 ,3(8), 1-7. Google Scholar

Sumitro A.dkk. 2017. Model Problem Based Learning Meningkatkan Motivasi dan Hasil Belajar IPS. Malang:Jurnal Pendidikan. Vol2 no9.

Suhasti S. dkk. 2019. Tradisi Literasi di Perguruan Tinggi Islam: Pandangan dan Motivasi para Penulis Jurnal Al-Ahwal UIN Sunan Kalijaga Yogyakarta. Yogyakarta: jurnal Al-Ahwal Vol II Nol. Google Scholar

Sugiyono, 2013, Metodelogi Penelitian Kuantitatif, Kualitatif Dan $\quad$ R\&D. $\quad$ (Bandung: ALFABETA)

Suwana, F. (2017). Empowering Indonesian women through building digital media literacy. Kasetsart Journal of Social Sciences, 38(3), 212-217. https://doi.org/10.1016/j.kjss.2016.10.004

(C) Diastuti, I., \& Sulton., A. (2020).

First Publication Right :

(C) Tapis : Jurnal Penelitian Ilmiah

This article is under:

CC BY SA 